\title{
Correlation and Path Coefficient Analysis in Ginger (Zingiber officinale Rose.)
}

\author{
Y. Ravi*, V.B. Narayanpur, J.S. Hiremath, S.S. Saraswati and M. Eragegowda \\ Department of Plantation, Spices, Medicinal and Aromatic Crops, Kittur Rani Channamma \\ College of Horticulture, Arabhavi - 591 218, Karnataka (India) \\ *Corresponding author
}

\section{A B S T R A C T}

\begin{tabular}{|l|}
\hline Key w or d s \\
Ginger, \\
$\begin{array}{l}\text { Genotypes, } \\
\text { Essential oil } \\
\text { and oleoresin. }\end{array}$ \\
\hline Article Info \\
\hline $\begin{array}{l}\text { Accepted: } \\
12 \text { March } 2017 \\
\text { Available Online: } \\
10 \text { April } 2017\end{array}$ \\
\hline
\end{tabular}

Sixteen genotypes of ginger collected from different parts of the country were evaluated in randomized block design with two replications during kharif 2014. The results on correlation and path analysis revealed high positive and significant association of fresh rhizome yield per hectare with characters viz., plant height, leaf area index, number of tillers per plant, number of leaves per plant, stem girth, number of primary rhizomes, length of primary rhizome, number of secondary rhizome, length of secondary rhizome, oleoresin content, curing percentage and essential oil content since, these characters also had high direct and indirect effect on fresh rhizome yield per hectare. Hence direct selection for these traits would be more useful in the improvement of yield per hectare.

\section{Introduction}

Ginger (Zingiber officinale Rose.) belongs to family Zingiberaceae and is one of the important and widely used spices throughout the world, for its universal appeal and lemon flavour has spread to tropical and subtropical countries from the Indo-China region, where ginger cultivation was prevalent from the days of unrecorded history (Nybe and Miniraj, 2005).

Ginger is used not only as a spice but also valued for its medicinal properties and plays an important role in primary health care. Apart from having tangy flavour, fresh rhizome has appreciable quantities of proteins $(2.3 \%)$, carbohydrates $(12 \%)$, fats $(1 \%)$, minerals $(1.2 \%)$, fibre $(2.5 \%)$ and moisture
(81 \%) of fresh rhizome (Swaminathan, 1974). Ginger is an herbaceous perennial, rhizomatous spice crop containing volatile oil, fixed oil, pungent compounds, resins, starch, protein and minerals. Among the many components, 'alpha zingiberene' is the predominating component of essential oil. 'Gingerol' and 'Shagoal' are responsible for the characteristic pungency of the ginger rhizome. The refreshing aroma and the pungent taste make ginger an essential ingredient of food and also in food processing industries worldwide. Ginger powder is also an essential ingredient in varieties of masala or spice mixes. Ginger is used in several food articles viz., bread, biscuit, cake, pudding, soup and pickle. According to the Indian 
system of medicine (Ayurveda), ginger rhizome is carminative and digestive. It is believed to be useful in dropsy, asthma, cough, diarrhoea, flatulence, nausea and vomiting. It is an ingredient in many ayurvedic preparations and is a folk cure for many ailments. Indian ginger in the world market is known for quality, which mainly comes from Kerala. Important ginger growing states in India are Kerala, Meghalaya, Orissa, West Bengal, Mizoram, Andhra Pradesh, and Karnataka. In India, it is grown in an area of $1,36,000$ hectares with an annual production of 6,83,000 MT with productivity of 5.0 MT per hectare (Anon., 2014).

In Karnataka, it is grown in an area of about 16.51 thousand hectares with an annual production of 57.80 thousand Million tons and with productivity $10.01 \mathrm{MT}$ per hectare. (Anon., 2012) It is mainly grown in the districts of Coorg, Shimoga, Bidar, Dakshina Kannada, Udupi, Bangalore, Uttar Kannada and Belgaum. Considering the importance of ginger as a spice and its medicinal value with low average productivity ( $4.9 \mathrm{MT} / \mathrm{ha})$, there is tremendous scope to increase the yield per unit area and there by the total production. A thorough knowledge of existing genetic variation and extent of association between various yield and yield contributing characters is essential for developing high yielding genotypes in ginger. Correlation and path analysis will establish the extent of association between yield and yield components and bring out the relative importance of their direct and indirect effects and thus give a clear understanding of their association with the yield.

\section{Materials and Methods}

\section{Experimental details}

The present investigation was carried out at the farm field of the division of Plantation, Spices, Medicinal and Aromatic Crops,
College of Horticulture, Sirsi (soppinabetta ecosystem) during 2014-15. Ginger genotypes were collected from different ginger growing areas along with released varieties viz., Mahima, Varada, Rajatha, Suravi, Suprabha. All these genotypes were evaluated in a randomized block design (RBD) with two replications. Each ginger genotype was planted in raised bed of $3.00 \mathrm{~m}$ length, $1.0 \mathrm{~m}$ width and $15 \mathrm{~cm}$ height at a spacing of $30 \mathrm{~cm}$ x $20 \mathrm{~cm}$. Intercultural operations were made as per package of practice recommended by University of Horticulture Science, Bagalkot (Anon, 2013).

\section{Statistical analysis}

The mean data were subjected to statistical analysis for estimating genetic parameters. Correlation coefficients at genotypic and phenotypic level were estimated by using formula suggested by Al-Jibouri et al., (1958) and path coefficient analysis using formula given by Dewey and Lu (1959).

\section{Results and Discussion}

In general genotypic correlation coefficients were higher than phenotypic correlation coefficients, which might be due to the masking effect of environment in the total expression of the genotypes resulting in reduced phenotypic association (Tables 1 and 2).

In the present study, the correlation study revealed that, fresh rhizome yield per hectare was positively and significantly correlated (both at $\mathrm{p}=0.01$ and at $\mathrm{p}=0.05$ ) with plant height, leaf area index, number of tillers per plant, stem girth, number of primary rhizomes, length of primary rhizome, number of secondary rhizome, length of secondary rhizome, oleoresin content, curing percentage, crude fibre content at both phenotypic and genotypic level. 
Table.1 Genotypic correlation for different growth, yield and its component characters in ginger genotypes

\begin{tabular}{|c|c|c|c|c|c|c|c|c|c|c|c|c|c|c|c|c|}
\hline & 1 & 2 & 3 & 4 & 5 & 6 & 7 & 8 & 9 & 10 & 11 & 12 & 13 & 14 & 15 & 16 \\
\hline 1 & 1.00 & 0.282 & $0.806 * *$ & $0.706 * *$ & $0.599 * *$ & $0.631 * *$ & $0.856^{* *}$ & 0.193 & $0.800 * *$ & $0.747 * *$ & 0.164 & 0.315 & $0.349^{*}$ & 0.24 & -0.049 & $0.877 * *$ \\
\hline 2 & & 1.00 & $0.772 * *$ & $0.479 * *$ & 0.122 & $0.400 *$ & $0.061 * *$ & -0.233 & $0.616^{* *}$ & 0.337 & -0.64 & 0.227 & $0.781^{* *}$ & $0.369^{*}$ & -0.027 & $0.417^{*}$ \\
\hline 3 & & & 1.00 & $0.471 * *$ & $0.614^{* *}$ & $0.423^{*}$ & 0.259 & 0.205 & $0.741 * *$ & $0.435^{*}$ & 0.08 & $0.590 * *$ & $0.482 * *$ & $0.755^{* *}$ & -0.165 & $0.779 * *$ \\
\hline 4 & & & & 1.00 & 0.161 & $0.830 * *$ & $0.551 * *$ & $0.474 * *$ & $0.998 * *$ & $0.556^{* *}$ & 0.049 & 0.089 & -0.097 & $0.552 * *$ & 0.218 & $0.602 * *$ \\
\hline 5 & & & & & 1.00 & 0.207 & $0.401 *$ & 0.07 & $0.480 * *$ & $0.511 * *$ & 0.138 & $0.488 * *$ & 0.204 & $0.449 * *$ & -0.275 & $0.563 * *$ \\
\hline 6 & & & & & & 1.00 & $0.417 *$ & 0.277 & $0.949 * *$ & 0.319 & -0.004 & 0.158 & -0.002 & $0.492 * *$ & 0.174 & $0.478 * *$ \\
\hline 7 & & & & & & & 1.00 & 0.178 & $0.638 * *$ & $0.999 * *$ & 0.086 & 0.043 & $0.353^{*}$ & 0.213 & 0.121 & $0.515 * *$ \\
\hline 8 & & & & & & & & 1.00 & $0.797 * *$ & -0.062 & $0.962 * *$ & 0.207 & $-0.370^{*}$ & $0.998^{* *}$ & 0.312 & 0.035 \\
\hline 9 & & & & & & & & & 1.00 & $0.538^{* *}$ & 0.197 & $0.441^{*}$ & -0.119 & $0.759 * *$ & 0.315 & $0.905 * *$ \\
\hline 10 & & & & & & & & & & 1.00 & $-0.513 * *$ & 0.322 & $0.428^{*}$ & 0.139 & -0.274 & $0.628 * *$ \\
\hline 11 & & & & & & & & & & & 1.00 & 0.265 & -0.184 & $0.736 * *$ & -0.242 & 0.073 \\
\hline 12 & & & & & & & & & & & & 1.00 & $0.404 *$ & $0.724 * *$ & $-0.628 * *$ & $0.621 * *$ \\
\hline 13 & & & & & & & & & & & & & 1.00 & -0.133 & -0.116 & $0.351^{*}$ \\
\hline 14 & & & & & & & & & & & & & & 1.00 & -0.302 & $0.573 * *$ \\
\hline 15 & & & & & & & & & & & & & & & 1.00 & $-0.503 * *$ \\
\hline 16 & & & & & & & & & & & & & & & & 1.00 \\
\hline
\end{tabular}

** Significant at $1 \%$ level $(0.448) *$ Significant at $5 \%$ level $(0.349)$

1-Plant height

plant

5- Stem girth

rhizome

9-Number of secondary rhizome

13-Essential oil content
2-Number of leaves per plant

6-Number of primary rhizome

10- Length of secondary rhizome 14-Curing percentage
3-Leaf area index

4-Number of tillers per

7-Length of primary rhizome

11- Girth of secondary rhizome 15-Crude fibre content
8-Girth of primary

12-Oleoresin content

16- Fresh yield per hectare 
Table.2 Phenotypic correlation for different growth, yeild and its component characters in ginger genotypes

\begin{tabular}{|c|c|c|c|c|c|c|c|c|c|c|c|c|c|c|c|c|}
\hline & 1 & 2 & 3 & 4 & 5 & 6 & 7 & 8 & 9 & 10 & 11 & 12 & 13 & 14 & 15 & 16 \\
\hline 1 & 1.00 & 0.124 & $0.492 * *$ & $0.480 *$ & $0.480 * *$ & 0.322 & $0.588 * *$ & -0.014 & $0.534 * *$ & $0.463 * *$ & 0.139 & 0.285 & -0.009 & $0.371 *$ & 0.039 & $0.700^{* *}$ \\
\hline 2 & & 1.00 & $0.565^{* *}$ & $0.349^{*}$ & 0.076 & 0.325 & 0.11 & -0.144 & $0.349 * *$ & 0.239 & -0.336 & 0.159 & 0.336 & 0.132 & 0.037 & $0.352 *$ \\
\hline 3 & & & 1.00 & 0.293 & $0.514 * *$ & $0.380 *$ & 0.226 & 0.102 & $0.494 * *$ & 0.238 & 0.045 & $0.463 * *$ & 0.265 & $0.497 * *$ & -0.075 & $0.634 * *$ \\
\hline 4 & & & & 1.00 & 0.169 & $0.584 * *$ & $0.413 *$ & 0.332 & $0.650 * *$ & $0.349 *$ & 0.077 & 0.087 & -0.081 & $0.431 *$ & 0.043 & $0.530 * *$ \\
\hline 5 & & & & & 1.00 & 0.115 & $0.377 *$ & 0.038 & 0.294 & $0.357 * *$ & 0.139 & $0.383^{*}$ & 0.153 & 0.255 & -0.303 & $0.514 * *$ \\
\hline 6 & & & & & & 1.00 & 0.218 & 0.225 & $0.543 * *$ & 0.21 & -0.008 & 0.102 & 0.042 & 0.228 & 0.224 & $0.414 *$ \\
\hline 7 & & & & & & & 1.00 & 0.08 & $0.371 *$ & $0.507 * *$ & 0.137 & 0.085 & 0.17 & 0.066 & 0.121 & $0.358 * *$ \\
\hline 8 & & & & & & & & 1.00 & 0.221 & -0.188 & $0.661 * *$ & 0.124 & -0.149 & $0.454 * *$ & 0.144 & 0.055 \\
\hline 9 & & & & & & & & & 1.00 & $0.579 * *$ & 0.153 & $0.404 *$ & -0.013 & $0.604 * *$ & 0.055 & $0.603 * *$ \\
\hline 10 & & & & & & & & & & 1.00 & -0.15 & 0.135 & 0.065 & 0.106 & -0.104 & $0.485^{* *}$ \\
\hline 11 & & & & & & & & & & & 1.00 & 0.175 & -0.27 & $0.349 *$ & 0.103 & 0.101 \\
\hline 12 & & & & & & & & & & & & 1.00 & 0.278 & $0.519 * *$ & -0.336 & $0.498 * *$ \\
\hline 13 & & & & & & & & & & & & & 1.00 & -0.109 & -0.252 & $0.421 *$ \\
\hline 14 & & & & & & & & & & & & & & 1.00 & -0.131 & $0.449 * *$ \\
\hline 15 & & & & & & & & & & & & & & & \begin{tabular}{|l|}
1.00 \\
\end{tabular} & $-0.389 *$ \\
\hline 16 & & & & & & & & & & & & & & & & 1.00 \\
\hline
\end{tabular}

** Significant at $1 \%$ level $(0.448)$

* Significant at $5 \%$ level (0.349)

1-Plant height 5- Stem girth 9-Number of secondary rhizome 13-Essential oil content
2-Number of leaves per plant

6-Number of primary rhizome
3-Leaf area index

7-Length of primary rhizome
4-Number of tillers per plant 8-Girth of primary rhizome
11- Girth of secondary rhizome 12-Oleoresin content 15-Crude fibre content
16- Fresh yield per hectare 
Table.3 Genotypic path coefficient analysis for fresh rhizome yield and its component characters

\begin{tabular}{|c|c|c|c|c|c|c|c|c|c|c|c|c|c|c|c|c|}
\hline & 1 & 2 & 3 & 4 & 5 & 6 & 7 & 8 & 9 & 10 & 11 & 12 & 13 & 14 & 15 & $\mathrm{rG}$ \\
\hline 1 & 0.440 & .135 & 0.014 & .646 & 0.003 & 0.056 & 0.167 & 0.284 & 1.482 & 0.112 & 0.072 & 0.007 & -0.128 & 0.256 & 0.124 & $0.877 * *$ \\
\hline 2 & .072 & 827 & 0.683 & 653 & 001 & -0.050 & .023 & .195 & .201 & 0.086 & 0.425 & .031 & .250 & .156 & 0.020 & $0.417^{*}$ \\
\hline 3 & 007 & 638 & 0.885 & 623 & & .053 & & & & & & & & 319 & .122 & $779 * *$ \\
\hline 4 & 337 & 396 & .416 & 448 & 0.001 & -0.103 & .210 & 0.396 & -2.024 & 0.141 & .033 & -0.012 & -0.031 & 0.233 & -0.161 & $0.602 * *$ \\
\hline 5 & & 101 & 0.544 & 555 & 0.009 & -0.026 & 0.153 & 0.059 & -0.936 & 0.130 & 0.092 & 0066 & 0.066 & .174 & 0.203 & $0.563^{* *}$ \\
\hline 6 & -0.198 & 330 & 0.374 & 2.862 & 0.002 & -0.125 & -0.159 & -0.232 & -1.852 & 0.081 & 0.003 & 0.021 & 0.001 & .208 & & $478 * *$ \\
\hline 7 & -0.192 & -0.050 & 0.229 & 1.898 & 0.004 & -0.052 & -0.382 & -0.149 & -1.245 & 0.289 & 0.057 & -0.006 & 0.113 & 0.090 & 0.089 & $0.515^{* *}$ \\
\hline 8 & .149 & 193 & 0.181 & 633 & 0.001 & -0.035 & 0.068 & 0.837 & -1.554 & -0.016 & 640 & -0.028 & -0.119 & 0.422 & 0.230 & 0.035 \\
\hline 9 & & 509 & 0.655 & 578 & .004 & -0.118 & .244 & & .950 & 0.136 & 131 & 0.060 & 0.038 & .320 & .000 & $0.905^{* *}$ \\
\hline & & -0.279 & 0.385 & 1.917 & 0.005 & -0.040 & & & & 0.254 & & & & 0.059 & 0.202 & $0.628 * *$ \\
\hline & -0.047 & 0.529 & 0.071 & 0.169 & 0.001 & 0.001 & -0.033 & -0.805 & -0.384 & -0.130 & 0.665 & -0.036 & -0.059 & 0.311 & -0.179 & 0.073 \\
\hline & 0.022 & -0.188 & 0.522 & 0.308 & 0.004 & -0.020 & -0.016 & -0.173 & -0.860 & 0.082 & 0.176 & -0.136 & 0.130 & 0.306 & 0.463 & $0.621 * *$ \\
\hline 3 & & & 0.426 & -0.335 & 0.002 & 0.000 & & & 0.232 & 0.108 & & & 0.321 & -0.056 & 0.086 & $0.351 *$ \\
\hline 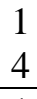 & -0.267 & -0.305 & 0.668 & 1.905 & 0.004 & -0.061 & & -0.837 & & 0.035 & 0.489 & -0.098 & -0.043 & 0.422 & 0.223 & $0.573 * *$ \\
\hline & -0.074 & 0.023 & -0.146 & 0.752 & -0.002 & -0.022 & -0.046 & -0.261 & 0.001 & -0.069 & 0.161 & 0.085 & -0.037 & -0.127 & -0.738 & $0.503^{-} * *$ \\
\hline
\end{tabular}

Diagonal indicates direct effect

Residual $=0.2863 \quad *$ Significant at $5 \% \quad * *$ Significant at $1 \% \quad \mathrm{rG}$ - Genotypic correlation with vegetable pod yield per plant

1-Plant height

5- Stem girth

9-Number of secondary rhizome

13-Essential oil content
2-Number of leaves per plant 3-Leaf area index

6-Number of primary rhizome

10- Length of secondary rhizome

14-Curing percentage
7-Length of primary rhizome

11- Girth of secondary rhizome

15-Crude fibre content
4-Number of tillers per plant 8-Girth of primary rhizome 12-Oleoresin content 16- Fresh yield per hectare 
It also positively and significantly correlated (only at $\mathrm{p}=0.05$ ) with number of leaves per plant and essential oil content at both genotypic and phenotypic level. Sreekumar et al., (1980) reported significant positive relationship of rhizome yield with plant height, number of tillers and number of leaves in study involving 30 ginger genotypes. These results are in agreement with findings of Kale (2001), Tomar et al., (2005), Rajyalakshmi et al., (2013), Shakeel and Kazuo (2013) and Prajapati et al., (2014).

The path coefficient analysis which splits total correlation coefficient of different characters into direct and indirect effects on fruit yield per plant in such a manner that the sum of direct and indirect effects is equal to total genotypic correlation as presented in table 3. The data revealed that number of tillers per plant showed high positive direct effect (3.488) on fresh rhizome yield per hectare followed by leaf area index $(0.885)$, girth of secondary rhizomes (0.665), curing percentage (0.422), essential oil content $(0.321)$, length of secondary rhizome $(0.254)$ and stem girth (0.009). These results are in accordance with Abraham and Latha (2003) and Rajyalakshmi et al., (2013). Number of secondary rhizomes (-1.950), girth of primary rhizome (-0.837), number of leaves per plant $(-0.827)$, crude fibre content $(-0.738)$, plant height $(-0.440)$, length of primary rhizome ($0.382)$, oleoresin content $(-0.136)$ and number of primary rhizomes (-0.125) showed negative direct effects on fresh rhizome yield per hectare, these results are similar with Shakeel and Kazuo (2013) and Prajapati et al., (2014).

Even though, number of secondary rhizomes was significantly and positively correlated with yield per hectare however, it had no direct effect (-1.950) on fresh rhizome yield, but it had high indirect and positive effect through number of tillers per plant (3.578), leaf area index (0.655), curing percentage
(0.320), length of secondary rhizome $(0.136)$ and girth of secondary rhizome $(0.131)$.

Girth of primary rhizome exhibited positive indirect effect on fresh yield through number of tillers per plant (1.633), girth of secondary rhizome (0.640), curing percentage (0.422), number of leaves per plant $(0.193)$ and leaf area index (0.181).

Similarly, Plant height had no direct effect (0.440 ), but it had positive indirect effect on fresh yield through number of tillers per plant (2.646), curing percentage (0.256), length of secondary rhizome $(0.112)$ and girth of secondary rhizome (0.072). Number of leaves per plant had indirect effect on fresh yield through number of tillers per plant (1.653), leaf area index (0.683), essential oil content $(0.250)$, girth of primary rhizome $(0.195)$ and curing percentage $(0.156)$. Number of primary rhizomes exhibited positive indirect effect on fresh yield through number of tillers per plant (2.862), leaf area index (0.374), curing percentage (0.208) and length of secondary rhizome (0.081). These results are in accordance with Kale (2001) and Tomar et al., (2005).

Girth of secondary rhizome exhibited no correlation with yield however; it had high direct effect (0.665) on fresh rhizome yield. Length of primary rhizome had positive indirect effect on fresh yield through number of tillers per plant (1.898), length of secondary rhizome (0.289), leaf area index (0.229), essential oil content (0.113), curing percentage (0.090) and girth of secondary rhizome (0.057).

Oleoresin content showed positive indirect effect on fresh yield through leaf area index (0.522), crude fibre content $(0.463)$, number of tillers per plant (0.308), curing percentage (0.306), girth of secondary rhizome $(0.176)$ and essential oil content (0.130). 
In conclusion, from the fore going discussions, it is conceivable that a great deal of success can be achieved in improvement of fresh yield per hectare by applying selection pressure on plant height, leaf area index, number of tillers per plant, number of leaves per plant, stem girth, number of primary rhizomes, length of primary rhizome, number of secondary rhizome, length of secondary rhizome, oleoresin content, curing percentage, and essential oil content since, these characters had significant positive correlation with fresh rhizome yield per hectare and also had high direct and indirect effects on fresh rhizome yield per hectare.

\section{References}

Abraham, Z. and Latha M. 2003.Correlation and path analysis in ginger (Zingiber officinale Rose.). J. Spices Aromatic crops., 12(2): 187-189.

Al-Jibouri, H.A., Miller, P.A. and Robinson, H.V. 1958. Genotypic and environmental variance and covariances in an upland cotton cross of inter specific origin. Agron. J., 50: 633636.

Anonymous. 2012. Horticultural crops statistics of Karnataka, Director of Horticulture, Lalbagh, Bangalore, p. 54.

Anonymous. 2014. Indian Horticulture Database, National Horticulture Board. 2013-2014. Ministry of Agriculture, Government of India, Gurgaon, P. 14.

Kale, U.B. 2001. Quality of ginger genotypes in the Ghataprabha left bank command area of Northern Karnataka. Karnataka
J. Agric. Sci., 16(4): 633-635.

Nybe, K.V. and Miniraj, N. 2005. Ginger production in India and other south Asian countries. Medicinal and Aromatic Plants, Industrial Profiles Crc Press pp. 211-240.

Prajapati, K.N. Patel, M.A., Patel, J.R., Joshi, N.R., Patel, A.D. and Patel, J.R. 2014. Genetic variability, character association and path coefficient analysis in Turmeric (Curcuma longa L.) Electronic J. Plant Breeding, 5(1): 131137.

Rajyalakshmi, R., Naidu, L.N., Rajasekhar, M. and Sudhavani, V. 2013. Genetic variability, correlation and path coefficient analysis in turmeric (Curcuma longa L.) J. Spices Aroma. Crops., 22(1): 104-107.

Shakeel, A. and Kazuo, N.W. 2013. Diversity analysis and relationships among ginger landraces, Pak. J. Bot., 45(4): 12031214.

Sreekumar, V., Indrasenan, G. and Mammen, M.K. 1980. Studies on the quantitative and qualitative attributes of ginger cultivars. Proceedings of National Seminar on Ginger and Turmeric. Calicut, pp.47-49.

Swaminathan, M. 1974. Essentials of food and nutrition, Volume II, Mysore printing and Publishing House, Mysore, pp. 484-485.

Tomar, N.S., Nair, S.K. and Gupta, C.R. 2005. Character association and path analysis for yield components in turmeric (Curcuma longa L.) J. Spices Arom. Crop., 14(1): 75-77.

\section{How to cite this article:}

Ravi, Y., V.B. Narayanpur, J.S. Hiremath, S.S. Saraswati and Eragegowda, M. 2017. Correlation and Path Coefficient Analysis in Ginger (Zingiber officinale Rose.). Int.J.Curr.Microbiol.App.Sci. 6(4): 1224-1230. doi: https://doi.org/10.20546/ijcmas.2017.604.150 